\title{
I Nivolumab in pediatric Hodgkin's lymphoma
}

\author{
Andrey V. Kozlov, Ilya V. Kazantzev, Tatyana V. Iukhta, Polina S. Tolkunova, Darya A. Zvyagintseva, Asmik G. Gevorgian, \\ Anton V. Malorodov, Kirill V. Lepik, Yury R. Zalyalov, Alexander N. Shvetsov, Anna V. Botina, Vadim V. Baykov, \\ Elena V. Morozova, Yury A. Punanov, Natalya B. Mikhailova, Ludmila S. Zubarovskaya, Boris V. Afanasyev \\ Raisa Gorbacheva Memorial Research Institute of Pediatric Oncology, Hematology and Transplantation, Pavlov University, \\ St. Petersburg, Russia
}

Dr. Andrey V. Kozlov, PhD, Raisa Gorbacheva Memorial Research Institute of Pediatric Oncology, Hematology and Transplantation, Pavlov University, L. Tolstoy St. 6-8, 197022, St. Petersburg, Russia

Citation: Kozlov AV, Kazantzev IV, Iukhta TV et al. Nivolumab in pediatric Hodgkin's lymphoma. Cell Ther Transplant 2019; 8(4): 41-48.

\section{Summary}

Immune checkpoint inhibitors (ICIs) are rather efficient in classical Hodgkin's lymphoma (cHL). Pembrolizum$\mathrm{ab}$ (pembro) is approved in children and demonstrates high response rates with acceptable toxicity. The role of nivolumab (nivo) in pediatric $\mathrm{cHL}$ is only to be elucidated. The aim of the presented study was to assess safety and efficiency of nivo in this age group with relapsed or refractory (R-R) cHL. Twenty-one pediatric heavily pre-treated patients 9-18 years old received nivo-based therapy. Overall response was registered in $86 \%$ (complete response - 57\% and partial response - 29\%).
Three-year overall survival (OS) and progression free survival (PFS) were $95 \%$ and $29 \%$, respectively. Only 1 clinically significant adverse effect (AE) of nivo was registered in the study (autoimmune thyroiditis). We did not observe any unacceptable toxicity of nivo.

\section{Keywords}

Children, Hodgkin's lymphoma, relapsed, refractory, nivolumab.

\section{Introduction}

Discovery and clinical success of ICIs entered a new era in oncology. The 2018 Nobel Prize in Medicine was awarded to James P. Allison and Tasuku Honjo "for their discovery of cancer therapy by inhibition of negative immune regulation". The principal role of immune system in tumor control was understood long ago. Earlier researchers mostly explored the opportunities to activate the immune system by stimulation of effector cells ("pressing gas pedal"). James P. Allison and Tasuku Honjo demonstrated that inhibition of checkpoints ("releasing the brake pedal") may effectively upregulate the immune system.

The ICIs demonstrate substantial efficiency in cHL. Pembrolizumab was approved for the treatment of children with $\mathrm{cHL}$, but the role of other ICIs in pediatrics should only to be elucidated. Despite impressive progress in oncology, the children with refractory or resistant (R-R) cHL still demonstrate suboptimal prognosis if $\geq 3$ lines of therapies have to be used [1]. This group of R-R cHL patients needs new approaches in management, and ICIs are among the most promising candidate drugs. The discovery of CIs introduced principally novel approach to cancer cure. This may convert cancer to one of chronic diseases [2].

The principal feature of immunity is the ability to differ between autoantigens and alloantigens. But the immune system is not ideal and regularly makes mistakes. These errors are often mild and non-significant but sometimes may lead to serious consequences such as oncological, autoimmune or infectious diseases. Studying molecular mechanisms of antigen procession, presentation, co-stimulation and inhibition is crucial for the treatment of patients with tumors.

PD-1 (programmed cell death-1) gene was discovered during the research of cell apoptosis [3]. It took a long journey to understand the function of PD-1 [2]. In terms of physiological role (immune inhibition) the definition of PD- 1 is relatively correct, due to fundamental position of apoptosis in tolerance. But, in general, the term PD-1 does not precisely reflect the function of the protein. 
Structurally PD-1 is a transmembrane protein and its interaction with ligands (PD-L1 or PD-L2) results in activation of PD-1/PD-L pathway $[4,5]$. This effect leads to downregulation of autoreactive $\mathrm{T}$ cells and upregulation of $\mathrm{T}$ regulatory cells [6]. Development of autoimmune disorders in the model of PD-1 knockout mice proved significance of the pathway for adequate immune regulation [7]. Excessive PD-1 expression due to continuous antigen stimulation results in T-cell exhaustion and tolerance [8]. This mechanism may be realized in tumors.

PD-1 and ligands are expressed constitutive or inducibly on many tissues. PD-1 is expressed on immune cells (T-helpers, cytotoxic T-lymphocytes, natural killers, B cells, monocytes and dendritic cells) [9]. PD-L1 has extensive distribution throughout the body while PD-L2 is only present on macrophages and dendritic cells. PD-L1 can be expressed on non-hematological structures, such as endothelial cells, fibroblasts, mucous, pancreatic islet cells, astrocytes, neurons, trophoblasts, retina, heart, placenta, skeletal muscle, lung and kidney $[10,11]$. Presence of PD-1 on endothelial cells may play an important role in the prevention of $\mathrm{T}$ cell migration into tissues and establishment of blood-organ immunological barriers [12]. Both PD-1 and PD-L1 are present on $\mathrm{T}$ cells, B-cells, macrophages and dendritic cells. These cells possess bimodal opportunity to regulate and to be regulated by the pathway. Some tumors also have PD-L1 on its surface, and it allows them to be "invisible" to immune system [13]. The expression of PD-1 and ligands is controlled by cytokines. For example, interferon 1 and tumor necrosis factor- $\alpha$ stimulate PD-L1 expression. Theoretically, combining these drugs with inducers of $\mathrm{PD}-1 / \mathrm{PD}-\mathrm{L} 1$ may improve the efficiency of ICIs.

Nivo and pembro are PD-1 blocking antibodies that have been approved by the U.S. Food and Drug Administration for the treatment of $\mathrm{cHL}$ and some solid tumors. They were also registered in Russian Federation for the management of adult patients (nivo and pembro) and children with cHL (pembro). In the majority of cHL patients, ICIs induce durable clinical response. Complete or partial recovery of tumor immune control results in significant attenuation of disease progression. Amplification of 9p24.1 and subsequent overexpression of PD-L1 seems to be the characteristic feature of HL-specific Reed-Sternberg cells [14]. It explains high efficiency of ICIs in cHL. However, most HL patients relapse after treatment with ICIs. Therefore, it is important to improve the results by shifting to combination therapy, incorporation of ICIs earlier in treatment and consolidation with HSCT [15]. We are only in the beginning of CIs era, and appropriate schemes and schedules are only to be discovered. For example, lower dosage of nivolumab could be comparable to standard dosage of $3 \mathrm{mg} / \mathrm{kg}$ biweekly [16].

The aim of our work was to assess safety and effectiveness of nivo in childhood R-R cHL.

\section{Patients and methods}

Twenty-one children and adolescents with R-R Hodgkin's lymphoma (HL) received nivo-based therapy in Raisa Gorbacheva Memorial Research Institute of Children Oncology,
Hematology and Transplantation, Pavlov First St. Petersburg State Medical University (see Table 1 for patient's characteristics). Median age was 16 years (9 to 18). Histological forms of HL were as follows: nodular sclerosis was diagnosed in 15 patients (71\%); mixed cellularity cHL, 4 cases (19\%), lymphocyte-rich cHL, 1 (5\%) and nodular lymphocyte predominant Hodgkin's lymphoma, 1 (5\%). At the onset of the disease, the early-stage favorable status was diagnosed in 4 patients (19\%); early-stage unfavorable or advanced disease was diagnosed in 17 cases (81\%). B-symptoms were documented in 12 patients $(67 \%)$. Bulky disease $(>7 \mathrm{~cm})$ and extranodal lesions were registered in 12 (57\%) and 14 (67\%) children, respectively. The disease was refractory in 9 cases (43\%), whereas resistant or multiple relapses occurred in 12 patients $(57 \%)$.

Median number of previous therapy lines was 4 (2-7) with radiation therapy in 14 patients (67\%), and autologous HSCT in 6 cases (29\%). Prior to nivo therapy, 16 children (76\%) had progression; 3 (14\%), stabilization, and 2 (10\%), partial remission according to Lugano criteria [17]. All the patients received nivo in an outpatient setting. Monotherapy was used in 13 (62\%) and combination with other drugs in $8(38 \%)$. In 5 children, combination therapy was indicated, based on opinion of attended physician. In 3 cases, other drugs were added after slow clinical response to the first nivo infusions, aiming to achieve faster clinical improvement. Treatment schedule consisted of $3 \mathrm{mg} / \mathrm{kg}$ of nivo biweekly in $11(52 \%)$ or $40 \mathrm{mg}$ of nivo biweekly in 10 (48\%). Combinations of nivo with following drugs were used: brentuximab vedotin $1.8 \mathrm{mg} / \mathrm{kg}$ triweekly $(\mathrm{n}=4)$ with median of 5 cycles (4-7), bendamustine $180 \mathrm{mg} / \mathrm{m}^{2}$ triweekly $(\mathrm{n}=3)$ with median of 5 cycles (5-7) and gemcitabine $1000 \mathrm{mg} / \mathrm{m}^{2}$ №5 weekly $(n=1)$. Median number of nivo cycles was 9 (2-28). Response to treatment was evaluated by the LYRIC criteria [18]. They represent modified Lugano recommendations, with the addition of indeterminate response (IR). This category describes possible pseudo-progression and allows to continue ICIs hoping for further best response without discontinuation of treatment in the patients with progressive disease according to previous criterial algorithms. After nivo-based treatment, 8 patients (38\%) received auto- or allogeneic hematopoietic stem cell transplantation (HSCT). Conditioning regimen in autologous HSCT $(n=4)$ was BeEAM (bendamustine, etoposide, cytarabine and melphalan). Haploidentical donors were employed in two allo-HSCTs, and two matched related siblings were used in two other cases. The conditioning regimen in allogeneic HSCT consisted of bendamustine $360 \mathrm{mg} / \mathrm{m}^{2}$ and Fludarabine $150 \mathrm{mg} / \mathrm{m}^{2}$. Graft-versus-host disease prophylaxis was based on posttransplant cyclophosphamide and calcineurin inhibitors. Radiation therapy was applied to consolidate the effect of nivo in 2 cases (10\%). Eleven patients $(52 \%)$ did not receive any consolidation treatment.

\section{Results}

Clinical response to nivo-based therapy was assessed in 21 patients (100\%). Efficiency of treatment is shown in Table 2. Overall response (ORR) was registered in 18 children ( $86 \%)$; $\mathrm{CR}$, in 12 cases (57\%); PR, in 6 patients (29\%) and IR, in 3 cases $(14 \%)$. Among the patients with IR, two children 
Table 1. Patient's characteristics $(\mathrm{n}=21)$

\begin{tabular}{|c|c|c|c|c|c|c|c|c|c|}
\hline HL & Age & Stage & Prior therapy & $\mathrm{R} / \mathrm{R}$ & Mono/Comb & $\begin{array}{l}\text { Nivo } \\
\text { (n) }\end{array}$ & $\begin{array}{l}\text { Response } \\
\text { to nivo }\end{array}$ & Follow-up & Status \\
\hline NSCHL & 16 & $\| \mathrm{A}$ & $\begin{array}{l}\text { ABVD, BEACOPP+RT, DHAP, ChVPP, GDP, } \\
\text { BV, vinblastin }\end{array}$ & rel & mono & 24 & CR & 1137 & $\begin{array}{l}\text { alive, } \\
\text { remission }\end{array}$ \\
\hline NSCHL & 16 & IIA & BEACOPP, DHAP, auto-HSCT & rel & comb & 12 & PR & 162 & $\begin{array}{l}\text { alive, } \\
\text { remission }\end{array}$ \\
\hline NSCHL & 15 & IVA & $\begin{array}{l}\text { OEPA/COPDAC, IEP/ABVD, DHAP, } \\
\text { BV+bendamustine }\end{array}$ & ref & comb & 12 & IR & 391 & $\begin{array}{l}\text { alive, } \\
\text { progression }\end{array}$ \\
\hline NSCHL & 16 & IIIB & $\begin{array}{l}\text { BEACOPP+RT, ICE, auto-HSCT, } \\
\text { bendamustine }\end{array}$ & ref & comb & 8 & $C R$ & 478 & $\begin{array}{l}\text { alive, } \\
\text { remission }\end{array}$ \\
\hline NSCHL & 18 & IIIB & $\begin{array}{l}\text { OPPA/COPP+RT, IEP, GemVin, DHAP, } \\
\text { BV+bendamustine }\end{array}$ & ref & mono & 9 & CR & 382 & $\begin{array}{l}\text { alive, } \\
\text { progression }\end{array}$ \\
\hline NSCHL & 18 & IVB & $\begin{array}{l}\text { OEPA/COPDAC+RT, IGEV, } \\
\text { BV+bendamustine, auto-HSCT }\end{array}$ & ref & mono & 6 & $C R$ & 91 & $\begin{array}{l}\text { alive, } \\
\text { remission }\end{array}$ \\
\hline MCCHL & 17 & IIB & $\begin{array}{l}\text { OEPA/COPDAC+RT, IEP/ABVD, auto-HSCT, } \\
\text { BV }\end{array}$ & ref & mono & 5 & CR & 237 & $\begin{array}{l}\text { alive, } \\
\text { remission }\end{array}$ \\
\hline MCCHL & 17 & IIA & BEACOPP, DHAP & $\mathrm{mr}$ & mono & 6 & PR & 105 & $\begin{array}{l}\text { alive, } \\
\text { remission }\end{array}$ \\
\hline NSCHL & 13 & IIA & BEACOP, DHAP, auto-HSCT, Gem0x & ref & mono & 6 & CR & 993 & $\begin{array}{l}\text { alive, } \\
\text { remission }\end{array}$ \\
\hline NSCHL & 17 & IIIB & $\begin{array}{l}\text { OEPA/COPDAC+RT, DHAP, IEP/ABVD, } \\
\text { bendamustine, BV }\end{array}$ & rel & mono & 10 & PR & 954 & $\begin{array}{l}\text { alive, } \\
\text { remission }\end{array}$ \\
\hline NSCHL & 16 & IIB & DAL/GPOH+RT, DHAP, IEP & rel & mono & 11 & PR & 305 & $\begin{array}{l}\text { alive, } \\
\text { progression }\end{array}$ \\
\hline NSCHL & 16 & IIIB & COPP, ABVD, DHAP, BV+bendamustine & rel & comb & 2 & PR & 65 & $\begin{array}{l}\text { dead, } \\
\text { progression }\end{array}$ \\
\hline NLPHL & 11 & IIIB & OEPA/COPDAC, IEP/ABVD, DHAP, BV & $\mathrm{mr}$ & mono & 12 & CR & 827 & $\begin{array}{l}\text { alive, } \\
\text { remission }\end{array}$ \\
\hline NSCHL & 17 & IVB & OEPA/COPDAC, ICE+RT, IGEV, BV & ref & mono & 10 & CR & 535 & $\begin{array}{l}\text { alive, } \\
\text { remission }\end{array}$ \\
\hline NSCHL & 10 & IIIB & $\begin{array}{l}\text { OEPA/COPDAC+RT, IEP/ABVD, BEACOPP, } \\
\text { IGEV }\end{array}$ & ref & comb & 4 & $\mathrm{PR}$ & 47 & $\begin{array}{l}\text { alive, } \\
\text { remission }\end{array}$ \\
\hline NSCHL & 14 & IIB & OEPA, ABVD, VIGEPP, IEP, BV & ref & mono & 12 & IR & 933 & $\begin{array}{l}\text { alive, } \\
\text { progression }\end{array}$ \\
\hline MCCHL & 18 & IIIA & $\begin{array}{l}\text { DAL-HD-90+RT, CEMP, MIV, } \\
\text { bendamustine, BV }\end{array}$ & $\mathrm{mr}$ & mono & 15 & CR & 447 & $\begin{array}{l}\text { alive, } \\
\text { progression }\end{array}$ \\
\hline LRCHL & 16 & IVB & BEACOPP, DHAP, BV & ref & comb & 7 & $C R$ & 318 & $\begin{array}{l}\text { alive, } \\
\text { remission }\end{array}$ \\
\hline NSCHL & 9 & IVB & BEACOPP, COPP/ABV, DHAP, BV, Gem0x & ref & comb & 28 & CR & 902 & $\begin{array}{l}\text { alive, } \\
\text { progression }\end{array}$ \\
\hline MCCHL & 13 & $\| A$ & $\begin{array}{l}\text { OEPA/COPDAC+RT, OEPA/BEACOPD, MIV, } \\
\text { bendamustine }\end{array}$ & rel & comb & 7 & CR & 606 & $\begin{array}{l}\text { alive, } \\
\text { remission }\end{array}$ \\
\hline NSCHL & 15 & IVB & OEPA/COPDAC, DHAP, BV & ref & comb & 3 & IR & 355 & $\begin{array}{l}\text { alive, } \\
\text { remission }\end{array}$ \\
\hline
\end{tabular}

Abbreviations: NSCHL (nodular sclerosis classical Hodgkin lymphoma), MCCHL (mixed cellularity classical Hodgkin lymphoma), NLPHL (nodular lymphocyte predominant Hodgkin's lymphoma), LRCHL (lymphocyte-rich classical Hodgkin lymphoma), OEPA/COPDAC (vincristine, etoposide, prednisolone, doxorubicin/cyclophosphamide, vincristine, prednisolone, dacarbazine), RT (radiotherapy), BEACOPP (bleomycin, etoposide, cytarabine, cyclophosphamide, vincristine, prednisolone, procarbazine), GDP (gemcitabine, dexamethasone, cisplatin), ABVD (doxorubicin, bleomycin, vinblastine, dacarbazine), DHAP (dexamethasone, cisplatin, cytarabine), ChVPP (chlorbutine, vinblastine, prednisolone, procarbazine), IEP/ABVD (ifosfamide, etoposide, prednisolone/doxorubicin, bleomycin, vinblastine, dacarbazine), VIGEPP (vinorelbine, gemcitabine, procarbazine, prednisolone), auto-HSCT (autologous hematopoietic stem cell transplantation), GemOx (gemcitabine, oxaliplatin), ICE (ifosfamide, carboplatin, etoposide), OPPA/COPP (vincristine, prednisolone, procarbazine, doxorubicin/cyclophosphamide, vincristine, prednisolone, procarbazine), IEP (ifosfamide, etoposide, prednisolone), IGEV (ifosfamide, gemcitabine, vinorelbine), COPP (cyclophosphamide, vincristine, prednisolone, procarbazine), CEMP (cyclophosphamide, etoposide, mitoxantron, prednisolone), COPP/ABV (cyclophosphamide, vincristine, prednisolone, procarbazine/doxorubicin, bleomycin, vinblastine), BV (brentuximab vedotin), rel (relapse), ref (refractory), $\mathrm{mr}$ (multiple relapses), mono/comb (monotherapy/combination therapy), R/R (relapsed/refractory), CR (complete response), PR (partial response), IR (indeterminate response), N/A - not applicable. 
relapsed, and one patient is now in remission with the follow-up of 355 days. Monotherapy resulted in ORR of $92 \%$ (12 patients); CR, in 62\% (8), and PR, in 30\% of cases (4). Combination therapy demonstrated similar effectiveness, i.e., ORR, 6 (75\%); CR, 4; (50\%); PR, 2 (25\%).

The three-year OS rates comprised 95\%. PFS rates at 1, 2 and 3 years were 69\%, 58\% and 29\%, respectively (Fig. 1A and 1B). Median OS was not reached. With median follow-up of 391 days (47-1137), twenty patients (95\%) were alive, and $14(67 \%)$ remained in remission state. Median PFS was 24 months. Consolidation with HSCT (auto- or allo-) resulted in 3-year PFS of 75\% (Fig. 2). Only 1 patient died in early posttransplant period due to infectious complications.
The general scheme of nivo-based therapy (mono- $v s$ combined treatment), cHL stage (early $v s$ advanced), tumor size (bulky+ vs bulky-), B symptoms, extranodal lesions, number of prior chemotherapy lines, preceding autoHSCT, number of nivo infusions (10vs $>10$, see Fig. 3), and complications of therapy did not affect OS and PFS ( $\mathrm{p}>0.1)$.

In the monotherapy group, complications of nivo were revealed in one adolescent $(7.7 \%)$. This patient developed autoimmune thyroiditis which required hormone replacement therapy. It didn't lead to discontinuation of the drug. In combination therapy group, 2 patients (25\%) developed transient cytopenias that could not be attributed solely to nivo and were probably associated with cytostatics.

Table 2. Efficiency of Nivolumab-based therapy

\begin{tabular}{|l|l|l|l|l|}
\hline Clinical response degree & All patients $(\mathbf{n}=21)$ & $\begin{array}{l}\text { Monotherapy } \\
(\mathbf{n = 1 3 )}\end{array}$ & $\begin{array}{l}\text { Combination } \\
(\mathbf{n}=8)\end{array}$ & $\mathbf{p}$ \\
\hline Overall response & $86 \%$ & $92 \%$ & $75 \%$ & 0.3 \\
\hline Complete response & $57 \%$ & $62 \%$ & $50 \%$ & NS \\
\hline Partial response & $29 \%$ & $30 \%$ & $25 \%$ & $25 \%$ \\
\hline Indeterminate response & $14 \%$ & $8 \%$ & & \\
\hline
\end{tabular}
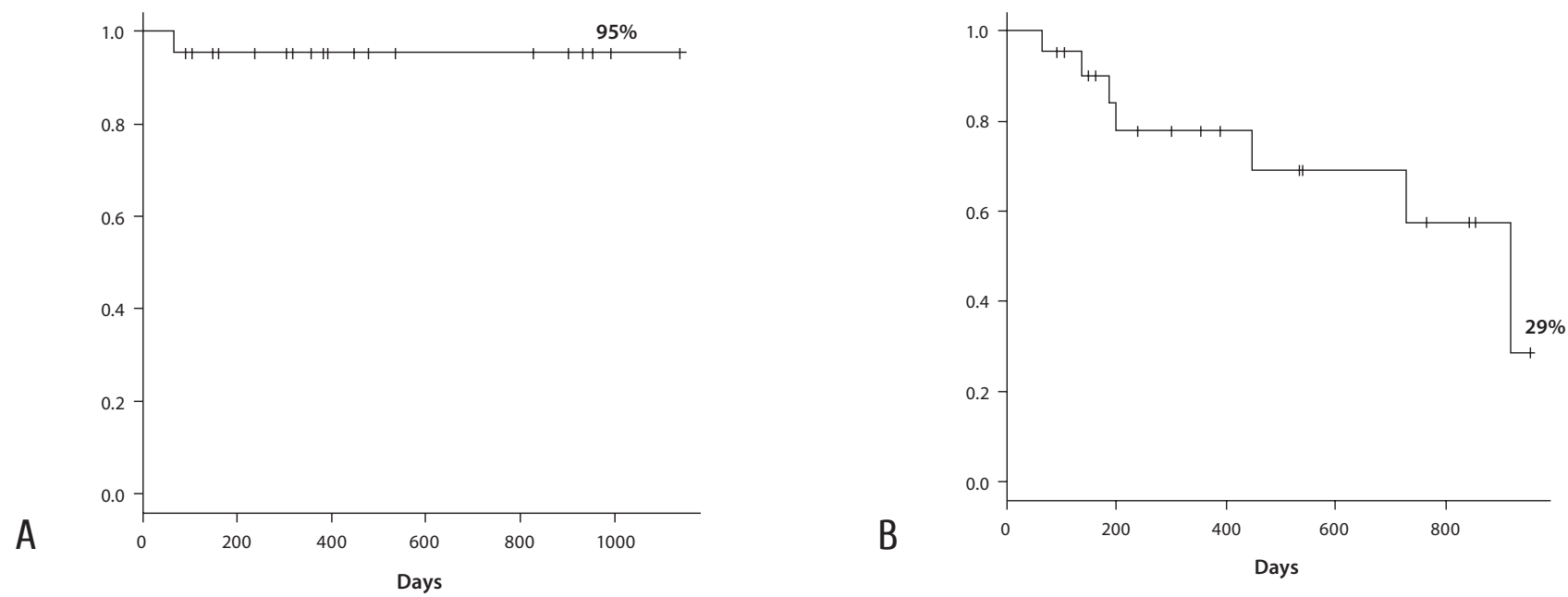

Figure 1. Overall survival (A) and progression-free survival (B) of the patients treated with nivolumab ( $\mathrm{n}=21)$

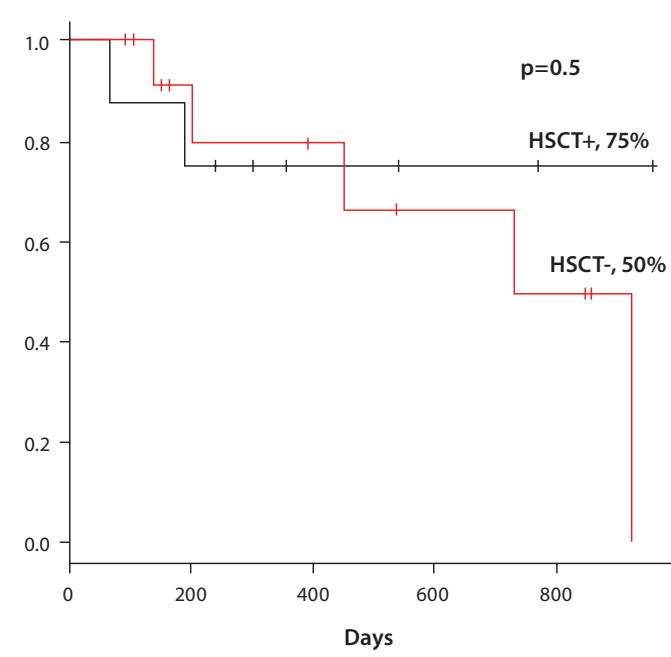

Figure 2. Progression-free survival curves with HSCT vs without following HSCT in the patients treated with nivolumab

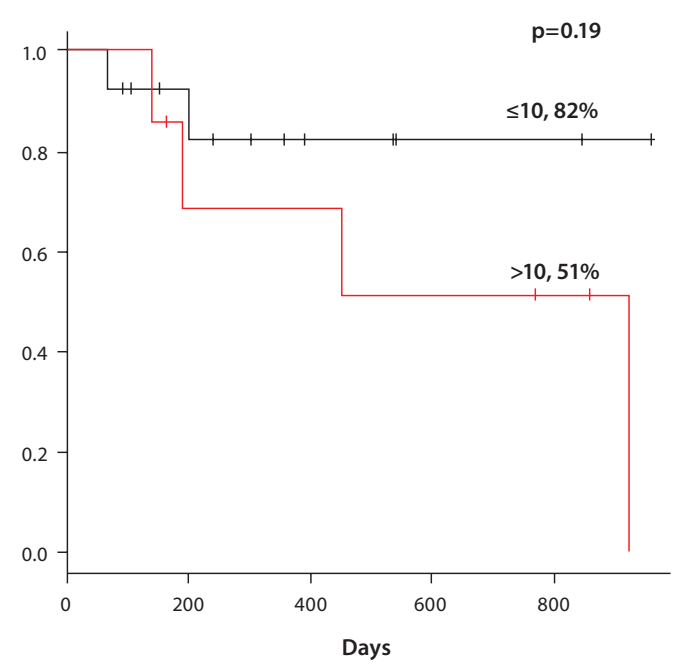

Figure 3. Progression-free survival curves among the patients treated with nivolumab ( $\leq 10$ vs >10 infusions). 


\section{Discussion}

ICIs have demonstrated high efficiency and acceptable safety profile both in adults and children in large cohorts of patients (Tables 3 and 4). Administration of ICIs in adult R-R HL results in overall response (ORR) of $64-82 \%$, with 2-year PFS of approximately $30 \%-58.5 \%[1,19]$. The largest pediatric trial with pembro included 125 children. This study clearly demonstrated safety of ICIs in children. Only 7 (6\%) had clinically significant adverse effects (grade 3-5). One patient $(0.8 \%)$ with renal carcinoma experienced pembro-associated pulmonary edema and died.

No major interferences on the developing immune system were observed [20]. Another important trial included children with R-R cHL treated with combination of nivo and brentuximab vedotin. Drug-related complications were registered in 32\% (grade 3-4) with neutropenia among the most common. Immune-mediated adverse effects were only grade 1-2 and included rash, hypersensitivity, infusion-related reactions and did not result in discontinuation of therapy [21].
In general, the results of the present study concerning nivo-based therapy in pediatric R-R cHL are in concordance with previously published data in adults and children [22]. Higher rates of CR in children and adolescents (57\%) compared to adults (15-36\%) may be associated with the differences of response evaluation in these studies, may represent a unique feature of pediatric sensitivity to ICIs or may be explained by limited patient number in the study $[23,24]$. Despite similar ORR in mono- and combined therapy arms, the data from other investigators strongly support the opinion that additional drugs improve the effects of nivo $[25,26]$.

Suboptimal 3-year PFS of 29\% in this heavily pretreated group (median number of prior lines -4) replicates earlier data of CIs administration in adults and children $[1,20]$. It is important to note that PFS rates at 1 and 2 years in our study are similar or higher than in above mentioned works and steadily decrease with time. It seems that PFS after nivo does not tend to reach plateau with time.

High ORR (86\%) after nivo in R-R cHL solves a challenge of remission induction and bridging to HSCT that is now

Table 3. Efficiency of immune checkpoint inhibitors in adult cHL

\begin{tabular}{|c|c|c|c|c|c|c|c|}
\hline Authors & $\begin{array}{l}\text { Checkpoint } \\
\text { inhibitor }\end{array}$ & $\begin{array}{l}\text { Median } \\
\text { number of } \\
\text { prior lines }\end{array}$ & $\begin{array}{l}\text { Number of } \\
\text { patients }\end{array}$ & $\begin{array}{l}\text { ORR (CR + } \\
\text { PR), \% }\end{array}$ & $\begin{array}{l}\text { Bridge to HSCT, } \\
\% \text {, comments }\end{array}$ & PFS\% & $\begin{array}{l}\text { Median PFS, } \\
\text { months }\end{array}$ \\
\hline $\begin{array}{l}\text { Armand P et al., } \\
2018\end{array}$ & Nivolumab & 4 & 243 & $69(16+53)$ & 18\% (allo) & $\begin{array}{l}\text { Approx. } 30 \% \\
\text { (at } 2 \text { years) }\end{array}$ & 14.7 \\
\hline $\begin{array}{l}\text { Chen R et al., } \\
2017\end{array}$ & Pembrolizumab & 4 & 210 & $69(22.4+46.6)$ & $\begin{array}{l}7 \% \\
\text { (auto and allo) }\end{array}$ & $\begin{array}{l}63.4 \% \\
\text { (at } 9 \text { months) }\end{array}$ & $\mathrm{N} / \mathrm{A}$ \\
\hline $\begin{array}{l}\text { Herrera AF et al., } \\
2018\end{array}$ & $\begin{array}{l}\text { Nivolumab + } \\
\text { Brentuximab } \\
\text { vedotin }\end{array}$ & 1 & 62 & $82(61+21)$ & $66 \%$ (auto) & $\begin{array}{l}89 \% \\
\text { (at } 6 \\
\text { months) }\end{array}$ & NR \\
\hline $\begin{array}{l}\text { Ansell S et al., } \\
2016\end{array}$ & $\begin{array}{l}\text { Nivolumab + } \\
\text { Ipilimumab }\end{array}$ & 4 & 31 & $74(19+55)$ & $\mathrm{N} / \mathrm{A}$ & N/A & N/A \\
\hline $\begin{array}{l}\text { Lepik KV et al., } \\
2018\end{array}$ & Nivolumab & 5 & 101 & $64(31.6+32.7)$ & N/A & $\begin{array}{l}40.6 \% \\
\text { (at } 2 \text { years) }\end{array}$ & 17.9 \\
\hline $\begin{array}{l}\text { Santoro A et al., } \\
2017\end{array}$ & Nivolumab & 4 & 133 & $68(15-53)$ & $\begin{array}{l}23 \% \\
\text { (auto and allo) }\end{array}$ & $\begin{array}{l}61.4 \\
\text { (at } 1 \text { year) }\end{array}$ & N/A \\
\hline $\begin{array}{l}\text { Ferhanoglu B et al., } \\
2019\end{array}$ & Nivolumab & 5 & 87 & $70(36+34)$ & $\begin{array}{l}15 \% \\
\text { (auto and allo) }\end{array}$ & $\begin{array}{l}58.5 \% \\
\text { (at } 2 \text { years) }\end{array}$ & $2-31$ \\
\hline
\end{tabular}

Abbreviations: ORR, overall response rate; CR, complete response; PR, partial response; HSCT, hematopoietic stem cell transplantation; PFS, progression-free survival; N/A, not applicable

Table 4. Efficiency of immune checkpoint inhibitors in pediatric cohorts

\begin{tabular}{|c|c|c|c|c|c|c|}
\hline Authors & $\begin{array}{l}\text { Checkpoint } \\
\text { inhibitor }\end{array}$ & $\begin{array}{l}\text { Total number of pts }(n) \text {, } \\
\text { comments }\end{array}$ & $\begin{array}{l}\text { ORR in all tum- } \\
\text { ors (CR + PR),\% }\end{array}$ & $\begin{array}{l}\text { ORR in HL } \\
(\mathrm{CR}+\mathrm{PR}), \%\end{array}$ & PFS in $\mathrm{HL}, \%$ & $\begin{array}{l}\text { Median } \\
\text { PFS in } \mathrm{HL} \\
\text { months }\end{array}$ \\
\hline $\begin{array}{l}\text { Geoerger B et al., } \\
2018\end{array}$ & Pembrolizumab & $\begin{array}{l}125 \text { (melanoma, solid } \\
\text { tumors, NHL, HL - 10) }\end{array}$ & 5.2 & $\begin{array}{l}60 \\
(10+50)\end{array}$ & $\begin{array}{l}56.3 \\
\text { (at } 1 \text { year) }\end{array}$ & 12.2 \\
\hline $\begin{array}{l}\text { Kelly KM et al., } \\
2019\end{array}$ & $\begin{array}{l}\text { Nivolumab + } \\
\text { Brentuximab vedotin }\end{array}$ & 31 (HL- 31) & $81(58+23)$ & $81(58+23)$ & N/A & N/A \\
\hline
\end{tabular}

Abbreviations: HL, Hodgkin's lymphoma; NHL, non- Hodgkin's lymphoma; ORR, overall response rate; CR, complete response; PR, partial response 
possible in the majority of children. There is an opinion of principal opportunity of ICIs to cure CHL but declining PFS curve argues it, and longer follow-up is needed to draw firm conclusion. Dissociation between high 3-year OS and low PFS marks a very characteristic feature of ICIs therapy in $\mathrm{cHL}$ that repairs immune tumor control and improves somatic status of a patient even in active disease. Slow subclinical progression probably is driven by other non-immune mechanisms of tumor escape. Median PFS in children and adolescents in our study is 24 months and well correlates with data in other publications [20]. Longer median PFS may be explained by combination of nivo with other drugs in $38 \%$. The positive effects of nivo significantly prolong life expectancy with good quality of life. Consolidation of nivo-induced remission with HSCT (auto or allo) results in 3 -year PFS of $75 \%$. HSCT is a potential option to improve cure rates after ICIs.

There is no established consensus opinion when to proceed with HSCT after ICIs, and what type of HSCT should be chosen. Allogeneic HSCT may be preferable, due to presumed sensitivity of the patients to immunotherapy. But autologous HSCT still may be effective in chemorefractory cases, since a recovery of chemosensitivity after ICIs treatment is hypothesized [27]. There are investigators that use both allo-HSCT and auto-HSCT to consolidate the ICIs effect $[22,24]$. At the same time, an impressively high 3-year OS rate $(95 \%)$ after nivo in our study, even in patients with progression, questions the need for transplantation at all [28]. Extensive follow-up is required to understand how long this clinical stabilization of cHL will continue in the majority of patients. In other words, can cHL be "cured" with morphologically and visibly obvious tumor, and if these patients may have a near-normal life expectancy similar to heathy people? This proposal seems more fantastic than real, and a longer follow-up is needed to see whether such observations will appear. Despite theoretical importance, the classical prognostic factors did not affect OS and PFS in our study. It may be explained by the domination of chemoresistance in our patients that minimizes the role of all other factors. Higher number of nivo cycles also did not improve outcome in our study. It emphasizes the challenging unsolved problem of optimal nivo treatment duration. Hypothetically, earlier consolidation with HSCT can minimize nivo-associated complications without loss of efficiency.

Only one clinically significant AE of nivo therapy was registered in the study, i.e., autoimmune thyroiditis which is a typical complication of the drug. Other characteristic autoimmune AEs were not encountered, probably due to limited patient number. All children and adolescents received nivo in outpatient setting, thus reflecting high tolerability and technical simplicity of treatment.

\section{Conclusion}

Nivo-based therapy is effective in the majority of children and adolescents with R-R cHL. In heavily pretreated patients, long-term PFS remains suboptimal, despite excellent OS levels. Consolidation with HSCT after nivo results in 75\% PFS at 3 years and should be considered in the majority of patients. Nivo-based therapy is relatively safe with only one clinically significant adverse effect (autoimmune thyroiditis) observed in our study. Nivo is technically simple and well tolerable treatment that is administered in an outpatient setting.

\section{Conflict of interest}

None declared.

\section{References}

1. Armand P, Engert A, Younes A, Fanale M, Santoro A, Zinzani PL, Timmerman JM, Collins GP, Ramchandren R, Cohen JB, De Boer JP, Kuruvilla J, Savage KJ, Trneny M, Shipp MA et al. Nivolumab for relapsed/refractory classic Hodgkin lymphoma after failure of autologous hematopoietic cell transplantation: extended follow-up of the multicohort single-arm phase II CheckMate 205 Trial. J Clin Oncol. 2018;36(14):1428-1439.

2. Honjo Tasuku - Nobel Lecture. NobelPrize.org. Nobel Media AB 2019. 19 Jul 2019. https://www.nobelprize.org/ prizes/medicine/2018/honjo/lecture/>

3. Ishida Y, Agata Y, Shibahara K, Honjo T. Induced expression of PD-1, a novel member of the immunoglobulin gene superfamily, upon programmed cell death. EMBO J. 1992;11(11):3887-3895.

4. Butte MJ, Keir ME, Phamduy TB, Sharpe AH, Freeman GJ. Programmed death-1 ligand 1 interacts specifically with the B7-1 costimulatory molecule to inhibit T cell responses. Immunity. 2007;27:111-122.

5. Elezov DS, Kudryavtsev IV. PD-1 receptor on immune cells, its expression and potential role in cancer therapy. Cell Ther Transplant, 2019; 8(2):8-16.

6. Francisco LM, Sage PT, Sharpe AH. The PD-1 pathway in tolerance and autoimmunity. Immunol Rev. 2010;236:219242 .

7. Yoshida T, Jiang F, Honjo T, Okazaki T. PD-1 deficiency reveals various tissue-specific autoimmunity by $\mathrm{H}-2 \mathrm{~b}$ and dose-dependent requirement of $\mathrm{H}-2 \mathrm{~g} 7$ for diabetes in NOD mice. Proc Natl Acad Sci USA. 2008;105(9):3533-3538.

8. Wherry EJ, Ha SJ, Kaech SM, Haining WN, Sarkar S, Kalia V, Subramaniam S, Blattman J, Barber DL, Ahmed R. Molecular signature of CD8+ T cell exhaustion during chronic viral infection. Immunity. 2007; 27(4):670-684.

9. Kabir TF, Chauhan A, Anthony L, Hildebrandt GC. Immune checkpoint inhibitors in pediatric solid tumors: status in 2018. Ochsner Journal.2018; 18(4):370-376.

10. Dong H, Zhu G, Tamada K, Chen L. B7-H1, a third member of the B7 family, co-stimulates T-cell proliferation and interleukin-10 secretion. Nat Med. 1999;5:1365-1369.

11. Suda T, Takahashi T, Golstein P, Nagata S. Molecular cloning and expression of the Fas ligand, a novel member of the tumor necrosis factor family. Cell. 1993;75:1169-1178.

12. Pittet CL, Newcombe J, Prat A, Arbour N. Human brain endothelial cells endeavor to immunoregulate CD8 T cells 
via PD-1 ligand expression in multiple sclerosis. J Neuroinflammation. 2011 Nov 8;8:155.

13. Meti N, Esfahani K, Johnson NA. The role of immune checkpoint inhibitors in classical Hodgkin lymphoma. Cancers (Basel). 2018;10(6):204. doi:10.3390/cancers10060204.

14. Lepik KV. Immune checkpoint inhibitors in the treatment of lymphomas. Clinical Oncohematology. 2018;11(4):303312 (In Russian).

15. Ansell SM. Beyond checkpoint inhibitors for Hodgkin lymphoma. 2018 Pan Pacific Lymphoma Conference. Invited Lecture. Presented July 19, 2018.

16. Lepik KV, Kozlov AV, Borzenkova ES, Popova MO, Moiseev IS, Darskaya EI, Gevorgyan AG, Tsvetkova LA, Bondarenko SN, Alyanskiy AL, Kondakova EV, Mikhailova NB, Afanasyev BV. Safety and efficacy of nivolumab applied at different dosage in the patients with relapsing Hodgkin lymphoma after allogeneic hematopoietic stem cell transplantation. Cell Ther Transplant. 2018; 7(2): 28-35.

17. Cheson BD, Fisher RI, Barrington SF, Cavalli F, Schwartz LH, Zucca E, Lister TA et al. Recommendations for Initial evaluation, staging, and response assessment of Hodgkin and non-Hodgkin lymphoma: the Lugano classification. J Clin Oncol. 2014;32(27):3059-3068.

18. Cheson BD, Ansell S, Schwartz L, Gordon LI, Advani R, Jacene HA, Hoos A, Barrington SF, Armand P. Refinement of the Lugano Classification lymphoma response criteria in the era of immunomodulatory therapy. 2016;128(21):24892496.

19. Ferhanoglu B, Ozbalak M, Bekoz H et al. Nivolumab for relapsed or refractory Hodgkin lymphoma: long term results of multi-center experience in Turkey. EHA Library. Jun 15, 2019; 266862; PS1245.

20. Geoerger B, Kang HJ, Yalon-Oren $M$ et al. KEYNOTE-051: An update on the phase 2 results of pembrolizumab (pembro) in pediatric patients (pts) with advanced melanoma or a PD-L1-positive advanced, relapsed or refractory solid tumor or lymphoma. J Clin Oncol. 2018; 36(15, Suppl):10525-10525.

21. Kelly KM, Daw S, Mauz-Körholz C , Mascarin M, Michel G, Cooper S, Beishuizen A, Leger KJ, Garaventa A, Buffardi S, Brugières L, Harker-Murray P, Cole PD. Response-adapted treatment with Nivolumab and brentuximab vedotin in young patients with relapsed/refractory classical Hodgkin lymphoma: CHECKMATE744 Subgroup analyses. Hematol Oncol. 2019;37: 56-57.

22. Chen R, Zinzani PL, Fanale MA, Armand P, Johnson NA, Brice P, Radford J, Ribrag V, Molin D, Vassilakopoulos TP, Tomita A, von Tresckow B, Shipp MA, Zhang Y, Ricart AD, Balakumaran A, Moskowitz $\mathrm{CH}$ et al. Phase II study of the efficacy and safety of pembrolizumab for relapsed/refractory classic Hodgkin lymphoma. J Clin Oncol 2017; 35(19):21252132 .

23. Lepik KV, Mikhailova NB, Kondakova EV, Tsvetkova LA, Zalyalov YR, Borzenkova ES, Moiseev IS, Baykov VV, Afanasyev BA. Efficacy and safety of nivolumab in the treatment of relapsed/refractory classical Hodgkin's lymphoma: Pavlov First Saint Petersburg State Medical University experience. Oncohematology. 2018;13(4):17-26. (In Russian).

24. Santoro A, D'alo' F, Zinzani PL et al. Real-world data of nivolumab in classical Hodgkin lymphoma: results from the Italian Expanded Access Programme. Blood. 2017; 130:5171.

25. Herrera AF, Moskowitz AJ, Bartlett NL, Vose JM, Ramchandren R, Feldman TA, LaCasce AS, Ansell SM, Moskowitz CH, Fenton K, Ogden CA, Taft D, Zhang Q, Kato K, Campbell $\mathrm{M}$, Advani RH. Interim results of brentuximab vedotin in combination with nivolumab in patients with relapsed or refractory Hodgkin lymphoma. Blood. 2018;131(11):11831194.

26. Ansell S et al: A phase 1 study of nivolumab in combination with ipilimumab for relapsed or refractory hematologic malignancies (CheckMate 039). 2016 ASH Annual Meeting. Abstract 183. December 5, 2016.

27. Dwary AD, Master S, Patel A, Cole C, Mansour R, Mills G, Koshy N, Peddi P, Burton G, Hammoud D, Beedupalli K. Excellent response to chemotherapy post immunotherapy. Oncotarget. 2017;8(53):91795-91802. doi:10.18632/oncotarget. 20030 .

28. Manson G, Mear JB, Herbaux C, Schiano JM, Casasnovas O, Stamatoullas A, Deau B, Schmitt A, Garnier G, Regny C, Bouabdallah K, Moles-Moreau MP, Ghesquieres H, Tempescul A, Dulery R et al. Long-term efficacy of anti-PD1 therapy in Hodgkin lymphoma with and without allogenic stem cell transplantation. Eur J Cancer. 2019; 115 (1):47-56. 


\title{
Применение ниволумаба у детей с лимфомой Ходжкина
}

\author{
Андрей В. Козлов, Илья В. Казанцев, Татьяна В. Юхта, Полина С. Толкунова, Дарья А. Звягинцева, \\ Асмик Г. Геворгян, Антон В. Малородов, Кирилл В. Лепик, Юрий Р. Залялов, Александр Н. Швецов, \\ Анна В. Ботина, Вадим В. Байков, Елена В. Морозова, Юрий А. Пунанов, Наталья Б. Михайлова, \\ Людмила С. Зубаровская, Борис В. Афанасьев \\ НИИ детской онкологии, гематологии и трансплантологии им. Р. М. Горбачевой, Первый Санкт-Петербургский \\ государственный медицинский университет им. акад. И. П. Павлова, Санкт-Петербург, Россия
}

\section{Резюме}

Ингибиторы контрольных точек показали высокую эффективность в лечении классической лимфомы Ходжкина (кЛХ). Пембролизумаб одобрен для применения у детей. Назначение данного препарата приводит к высокой частоте ответа на терапию и является относительно безопасным. Роль ниволумаба у детей с кЛХ еще только предстоит определить. Целями представленной работы были оценка эффективности и оценка побочных эффектов у детей с рецидивирующим и рефрактерным течением кЛХ. Терапия на основе ниволумаба была проведена у 21-го предлеченного пациента (9-18 лет) с кЛХ. Общий ответ отмечался у 86 \% (полный ответ - 57\% и частичный ответ - 29\%). Трехлетняя общая выживаемость и выживаемость без прогрессирования составили $95 \%$ и 29\%, соответственно. Отмечалось только одно клинически значимое осложнение ниволумаба (аутоиммунный тиреоидит). Не было зарегистрировано тяжелых побочных явлений проводимой терапии.

\section{Ключевые слова}

Лимфома Ходжкина, рецидивирующая, рефрактерное течение, дети, ниволумаб. 